\title{
Comparative analysis on the levels of some bioactive constituents of Asian and African garlic types
}

\author{
Nuha Mohammed Elhassan Satti ${ }^{1}$, Ishraga Eltayeb Mohamed A-Elbasit², Fatima Abdallah \\ Mohammed Ahmed ${ }^{3}$ and Sharaf Eldin Hussain Eltahir ${ }^{4 *}$ \\ ${ }^{1}$ Assistant Professor, Department of Biology, College of Arts and Science, Northern Border University \\ Kingdom of Saudi Arabia, Rafah City \\ ${ }^{2}$ Associate Professor, Department of Basic Health Science, Faculty of Pharmacy, Northern Border University. \\ Kingdom of Saudi Arabia, Rafah City \\ ${ }^{3}$ Assistant Professor, Department of Biology, College of Arts and Science, Northern Border University \\ Kingdom of Saudi Arabia, Rafah City \\ ${ }^{4}$ Doctor of Forensic Sciences and Biochemistry, Collaborate Researcher, Forensic Sciences Institute, National \\ Ribat University, Khartoum, Sudan
}

\begin{abstract}
The present study investigates the comparative levels of some bioactive constituents of the important plant Allium sativum (garlic). Comparisons have been made on the levels within three garlic types, one type from Asia (Chinese garlic), and two African garlic types from Sudan. Results showed that the garlic from South-western Sudan (Zalenge region) had higher levels concerning most of the constituents, particularly it contains $38.17 \pm 1.26 \mathrm{~g} / 100 \mathrm{~g}$ of carbohydrate, $2.53 \pm 0.45 \mathrm{~g} / 100 \mathrm{~g}$ fat, $110.00 \pm 2.45 \mathrm{mg} / 100 \mathrm{~g}$ phosphorus, and $185.22 \pm 2.47 \mathrm{mg} / 100 \mathrm{~g}$ calcium as compared to $29.00 \pm 1.00$ $\mathrm{g} / 100 \mathrm{~g}, 1.23 \pm 0.25 \mathrm{~g} / 100 \mathrm{~g}, 90.22 \pm 1.66 \mathrm{mg} / 100 \mathrm{~g}$, and $176.60 \pm 1.20 \mathrm{mg} / 100 \mathrm{~g}$, respectively of the Northern Sudan garlic, and $23.97 \pm 1.06 \mathrm{~g} / 100 \mathrm{~g}, 0.57 \pm 0.21 \mathrm{~g} / 100 \mathrm{~g}, 99.11 \pm 3.72 \mathrm{mg} / 100 \mathrm{~g}$, and $148.21 \pm 3.28 \mathrm{mg} / 100 \mathrm{~g}$, respectively of the Chinese garlic. The variations were almost due to the enriched soil of that region of Sudan which is known as a source of many plant products, either cultivated or naturally grown. The justification for the uncertainty of results of allicin levels in garlic samples had been discussed.
\end{abstract}

KEY WORDS: ALLIUM SATIVUM, CHINESE, CONSTITUENTS, GARLIC, NORTHERN SUDAN, ZALENGE

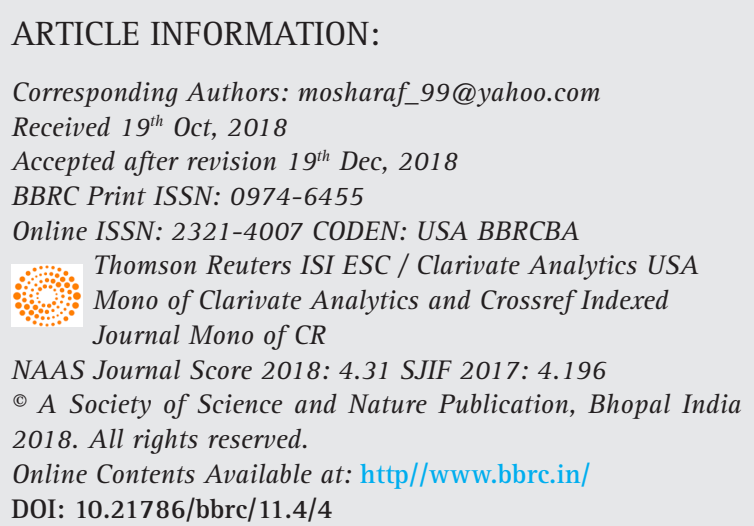




\section{INTRODUCTION}

The botanical name of garlic is (Allium sativum L., Amaryllidaceae) (Cruz and García 2007, Block 2010). Common garlic is classified as Allium sativum, British wild garlic as Allium oleraceum, and American wild garlic as Allium candense (Block 2010). The plant is likely to have originated from Central Asia, USA, Central America, Iran, and Egypt. It is now cultivated worldwide, but China provides $80 \%$ of the total world production (Cruz 2007). The garlic plant is one of the most popular herbs (traditional medicine) and spices (food flavoring agent) in the world, (Butt et al. 2009). There are more than 70 garlic varieties. Garlic is a bulb-shaped plant belongs to the onion family, it is close relative to the onion and resembles it in size and growth habit. The plant grows as a vegetable rosette close to the ground, (Block 2010, Renton 2013 and FAOSTAT 2017).

Garlic (Allium satvium L.) is an important vegetable crop in the Northern, Central, and Western Sudan (River Nile State and Darfur State) during the winter season, (October - March) (Ahmed et al. 1984, Nouria 1994, Mohammed Ali and El-Sayed 1999, Factfish website 2017). However, the production of garlic in Sudan is humble as compared to its enormous agricultural potential, it is ranked as the 22nd in the world, (Factfish website 2017). Sudanese variety of garlic is preferred for its strong odor and flavor compared to that imported from South Asian region, although the latter is bigger in size and easy in peeling.Usually, the garlic bulb (head) consists of (6 to 35) discrete bulblets called cloves. In Allium sativum there are 10-12 cloves per bulb and Allium porrum is a single clove type of garlic. Each garlic clove is made up of just one leaf base, unlike onions, which are composed of numerous leaf layers, (Shah and Qudry 1996 Muhammad Ibrahim et al. 2018).

The storage part of the garlic plant is the clove and not the leaves (Libner Nonnecke 1989). The characteristic pungent odor, the unique flavor, aroma, and biological effects of garlic are generally attributed to its organosulfur components (particularly allicin) (Block 2010, Shah and Qudry 1996), in addition to diallyl trisulfide (DATS) and diallyl disulfide (DADS) and derivatives which are released from garlic upon their processing (mincing, chewing and etc.) (Makoto et al. 2006 Block 2010).

The allicin generated from garlic is unstable so it quickly changes into a series of other sulfur-containing compounds such as diallyl disulfide (by the enzyme alliinase), therefore the garlic should be consumed immediately after crushing (Cavallito et al. 1944). Allicin has a very short half-life breaking down within 16 hours at $23{ }^{\circ} \mathrm{C}$ (Hahn 1996), and it is very volatile, so it takes a lot of garlic to gain those benefits (Lanzotti 2005). Harris et al., stated that allicin decomposes rapidly and some smaller metabolic breakdown products also exert strong antimicrobial effects (Harris et al 2001). Alliin is a derivative of the amino acid cysteine, and it is not present in garlic unless tissue damage occurs, (Iberl et al., 1990).

Alliin transforms to allicin on crushing the natural garlic cloves or bulb, so the commercial garlic preparations may contain no allicin. Allicin first reported by Cavallito and Bailey in 1944, and then Cavallito first noted its potent antimicrobial activity (Cavallito et al. 1944). Many researchers found that the allicin quantity depends on the cultivation region and harvest date, and fertilization especially with sulfur (Block 2010). But Baghalian reported no significant correlation between the ecological condition and the allicin content (Baghalian et al. 2005). Out of different garlic extracts, the "Aged Garlic Extract" (AGE) is the prominent one, with the highest antioxidant activity, even more than fresh garlic and other commercial garlic supplements. AGE contains phytochemicals (tannins, flavonoid, Saponin and glycoside) and also contains phenolic compounds, alkaloids, terpenoids and fatty acids (Butt et al. 2009, Shah and Qudry 1996). Crushed raw garlic is high in allicin, containing $37 \mathrm{mg} / \mathrm{g}$. Allicin content found ranged from 0.16-13.0 mg/g in Iranian garlic ecotypes, measured by HPLC method (Baghalian et al. 2005).

Differences in the concentrations of organosulfur compounds in different garlic types may affect the medicinal properties of the garlic (Block 2010, Hassan Khalid et al. 2012, Huzaifa et al. 2014). In addition to these organosulfur compounds, fresh garlic is a source of numerous vitamins like vitamins B-6 and C, and minerals although their quantities may vary depending on the type of soil on which they are cultivated (Stephen $\&$ John 2000).

The long history of the medicinal use of garlic is welldocumented. Since the time of Louis Pasteur (1858) and Lehmann (1930), garlic was used as an antibacterial agent, and till recent time studies were conducted on garlic as an inhibitor of bacterial growth (Alejandra et al. 2010). The properties of garlic against atherosclerosis, coronary thrombosis, myocardial infarction, and its inhibition of platelet aggregation and the proliferation of cancer cells had been reported (Lawson 1992). Traditionally garlic is known as an important antiseptic, and it has hypotensive, anthelmintic, chloretic and expectorant properties, it shows a hypoglycemic activity (Beretz and Cazenave 1991, Lawson, Ransom and Hughes 1992, Mostofa et al. 2007). It is used to treat intestinal infection (Cavallito et al. 1944), and treats ailments like diarrhea, headache, and dysentery and showed to have antifungal (Saha and Bandyopadhyay 2017), antibacterial, antiviral, antiprotozoal, and antifungal activity. Garlic inhibits the growth of both bacteria and fungi (Saha and Bandyopadhyay 2017, Emad Mohamed Abdallah 2017). 
It has antioxidant properties, increases the levels of antioxidant enzymes of the liver, so reduce inflammation (Sha Li et al 2015, Hassan Khalid 2012). Garlic can help to chelate heavy metals and promote their excretion by the body (Ashraf Nasr 2014). The effectiveness of garlic may be prevention rather than therapy, thus it may need long-term supplementation (Leyla Bayan et al 2014). The mechanism by which allicin treats infections in people seems to be unclear. This study compares the levels of some bioactive constituents of three types of garlic, Chinese garlic (the most produced Asian garlic), and the Sudanese garlic (African garlic type) which had been represented by two types, one from Northern Sudan, and the second type is from South-western Sudan, a region called Zalengei located in Darfur State. This last garlic type would be mentioned as "Zalengei garlic" throughout this study, as it is a common local name in Sudan.

\section{MATERIAL AND METHODS}

Samples of three types of garlic were collected, two types were from Sudan (One from Northern Sudan and the other from South-western Sudan - Zalengie -), the third type was a Chinese garlic purchased from Omdurman local market. These types had been confirmed and authenticated by a collective agreement of specialized Doctors and technicians of the concerned laboratories and herbarium section, in addition to the collective opinions of the importing and exporting experts working in this field.A series of laboratory experiments were undertaken at the College of Agricultural Studies, Sudan University of Science and Technology at Shambat. Garlic fruits were then crushed using grinding machine.

Extraction method: 100 grams of each sample were weighted into $1000 \mathrm{ml}$ conical flask using sensitive balance; Samples extracted using of Ethanol 70\% (500 ml) in a shaker $200 \mathrm{rpm}$ for $24 \mathrm{~h}$ at room temperature and subsequently filtrated under suction (reduce pressure using vacuum pump), extract samples were transferred to ice form using $\left(-20 \mathrm{C}^{\circ}\right)$ refrigerator and dried using freeze dryer machine $\left(-50 \mathrm{C}^{\circ}\right.$ for $\left.48 \mathrm{~h}\right)$. Dry samples were collected and kept in vials till used.

The moisture content was determined according to of the Association of Official Analytical Chemists (AOAC, 2008). Two grams were weighed into a pre-dried and tarred dish. Then, the sample was placed into an oven (No.03-822, FN 400, Turkey) at $105^{\circ} \mathrm{C} \pm 1{ }^{\circ} \mathrm{C}$ until a constant weight was obtained. After drying, the covered sample was transferred to a desiccator and cooled to room temperature before reweighing. Triplicate results were obtained for each sample and the mean value was reported according to the following formula;

\section{Calculation:}

$$
\text { Moisture content }(\%)=\frac{W 1-W 2}{W t 1} \times 100
$$

Where;

W1 = Sample weight before drying

W2 =Sample weight after drying

Wt1=initial sample weight

The ash content was determined according to the method described by Pearson (1981). Five grams were weighed into a pre-heated, cooled, weighed and tarred porcelain crucible and placed into a Muffle furnace (No.20. 301870, Carbolite, England) at 550 to $600{ }^{\circ} \mathrm{C}$ until a white-gray ash was obtained. The crucible was transferred to a desiccator then allowed to cool to room temperature and weighed. After that, the ash content was calculated as a percentage based on the initial weight of the sample.

\section{Calculation:}

Ash $\%=[($ Wt of crucible + Ash $)-($ Wt of empty crucible $] \times 100$ Initial weight $(\mathrm{Wt})$

Crude fiber content was determined according to the official method of the AOAC (2008). Two gram of a defatted sample was placed into a conical flask containing $20 \mathrm{~m} 1$ of $\mathrm{H}_{2} \mathrm{SO}_{4}(0.26 \mathrm{~N})$. condensed and allowed to boil for 30 minutes. the digest was filtered (under vacuum). rinsed and boiled in $20 \mathrm{ml} \mathrm{NaOH}(0.23 \mathrm{~N})$ solution for $30 \mathrm{~min}$ under reflux condenser and the precipitate was filtered, rinsed with hot distilled water, 20m1 ethyl alcohol (96\%) and $20 \mathrm{ml}$ diethyl ether. Finally, the crucible was dried at $105{ }^{\circ} \mathrm{C}$ (overnight) to a constant weight, cooled (in a desiccator), weighed, ashed in a Muffle furnace (No.20. 301870 , Carbolite, England) at $550-600{ }^{\circ} \mathrm{C}$ until a constant weight was obtained and the difference in weight was considered as crude fiber.

\section{Calculation:}

Crude

$\%=[$ Dry residue crucible Cal] $-[$ ignited residue + crucible $(\mathrm{g})] \times 100$

$$
\text { Sample weight }
$$

The protein content was determined in all samples by micro-Kjeldahl method using a copper sulphate-sodium sulphate catalyst according to the official method of the AOAC (2008). Two gram sample was transferred together with $4 \mathrm{~g} \mathrm{Na}_{2} \mathrm{SO}_{4}$ of Kjeldahl catalysts (No. 0665, Scharlau chemie, Spain) and $25 \mathrm{~m} 1$ of concentrated sulphuric acid (No. 0548111, HDWIC, India) into a Kjeldahl digestion flask. After that, the flask was placed into a Kjeldahl digestion unit (No. 4071477, type KI 26, Gerhardt, Germany) for about 2 hours until a colourless digest was obtained and the flask was left to Cool to room temperature. The distillation of ammonia was carried out into 
$25 \mathrm{~m} 1$ boric acid (2\%) by using $20 \mathrm{~m} 1$ distilled. water and $70 \mathrm{~m} 1$ sodium hydroxide solution (45\%). Finally, the distillate was titrated with standard solution of HCI $(0.1 \mathrm{~N})$ in the presence of 2-3 drops of bromocresol green and methyl red as an indicator until a brown reddish colour was observed.

\section{Calculation:}

Nitrogen $\%=$ Titre volume $\times \mathrm{HCl}(\mathrm{N}) \times$ Nitrogen equivalent weight $\times 100$ Sample weight $\times 1000$

Crude protein $\%=$ Nitrogen $\%$ x Protein conversion factor (6.25)

Total and available carbohydrates were calculated by difference according to the following equations:

Total carbohydrates $=100-$ (Moisture + Protein + Fat + Ash)

Available carbohydrates $=$ Total carbohydrates - Crude fiber.

Fat content was determined according to the official method of AOAC (2008).

Samples had been put in extraction thimble, then about $100 \mathrm{ml}$ hexane were attached to the extraction unit (Electrothermal, England), after $16 \mathrm{hr}$ extraction process, the solvent was redistilled, put in an oven at 105 . for $3 \mathrm{hr}$, cooled in a desiccator, reweighed and the dried extract was registered as fat content according to the following formula;

\section{Calculation:}

$$
\text { Fat content }(\%) \quad=\frac{(W 2-W 1)}{W 3} \times 100
$$

Where;

W2 =Weight of the flask and ether extract

$\mathrm{W} 1=$ Weight of the empty flask

W3=initial weight of the sample

To analyze the minerals content, Samples were placed into a muffle furnace (No.20. 301870, Carbolite, England) at 550 to $600{ }^{\circ} \mathrm{C}$. the ash content was cooled and $10 \mathrm{ml}$ of HCI $(2.0 \mathrm{~N})$ was added. the concentrations of Minerals were determined using, Atomic Absorption Spectrophotometer (3110-Perkin Elmer. USA).The investigation of alliin and allicin (thiosulfinates) concentrations in garlic bulbs were determined using HPLC methods according to Iberl (1990).

\section{RESULTS AND DISCUSSION}

The physical appearance and the size of bulbs (and cloves) variations between the tested three samples were shown in (Fig 1).

Apparently and physically, the Zalenge garlic has more flavor, stronger taste, and it has smaller blub and cloves and darker color than both the Northern-Sudan garlic and the Chinese garlic (Fig 2).

Regardless of these results, the flavor is very subjective and personal, and there is not truly accurate scientific measurement for it. Zalenge garlic is denser and heavier (more solid). It is rarely found in the national markets because of its low production in that region of the Sudan which is suffering under national war and social conflicts.

Our findings of the measured parameters of the three garlic types, North-Sudan garlic, Zalenge garlic, and Chinese garlic, were shown in (Table1).

The low moisture content of Zalenge garlic (40.97\%) compared to the other garlic samples and other garlic types reported by previous studies may lead to higher concentrations of the garlic clove constituents, i.e. create more dense clove. The two Sudanese garlic types (South-Sudan, and Zalenge) had an almost similar protein content $(6.50 \mathrm{~g} / 100 \mathrm{~g}$, and $6.73 \mathrm{~g} / 100 \mathrm{~g}$, respectively), but Zalenge garlic had a higher carbohydrate content $(38.17 \mathrm{~g} / 100 \mathrm{~g})$, and fat content $(2.53 \mathrm{~g} / 100 \mathrm{~g})$. The levels of the phosphorus and calcium were higher in the Zalenge garlic (110.00 mg/100g, $185.22 \mathrm{mg} / 100 \mathrm{~g}$, res.) than levels we found in North-Sudan garlic, but they were simi-

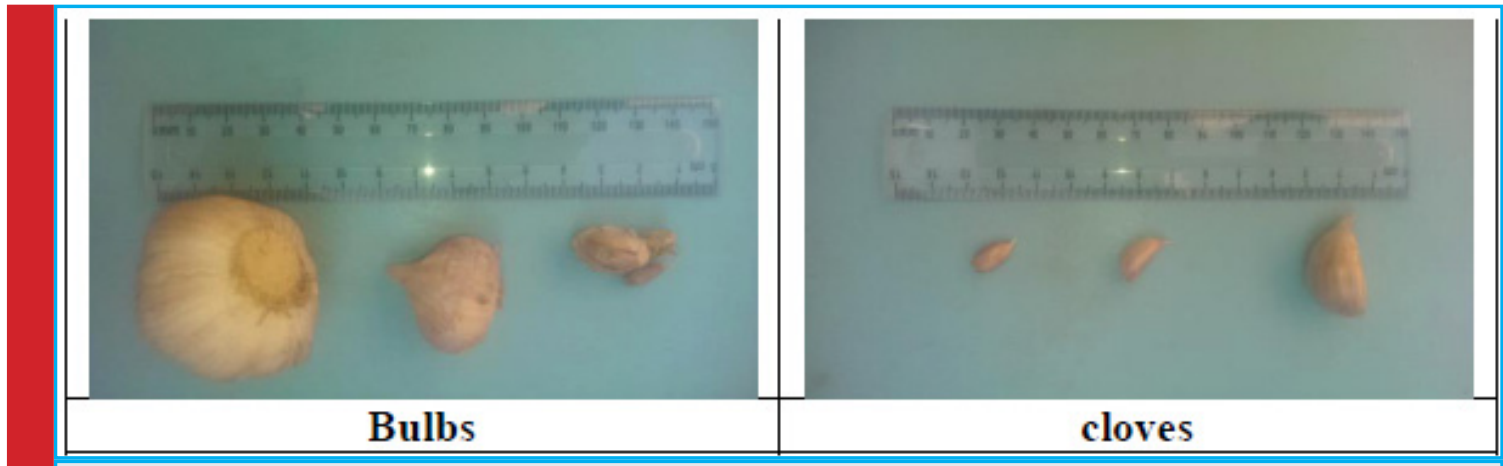

FIGURE 1. Appearance and size of the studied garlic types [The largest: Chinese garlic; The medium: Northern Sudan garlic; The smallest: Zalenge garlic] 


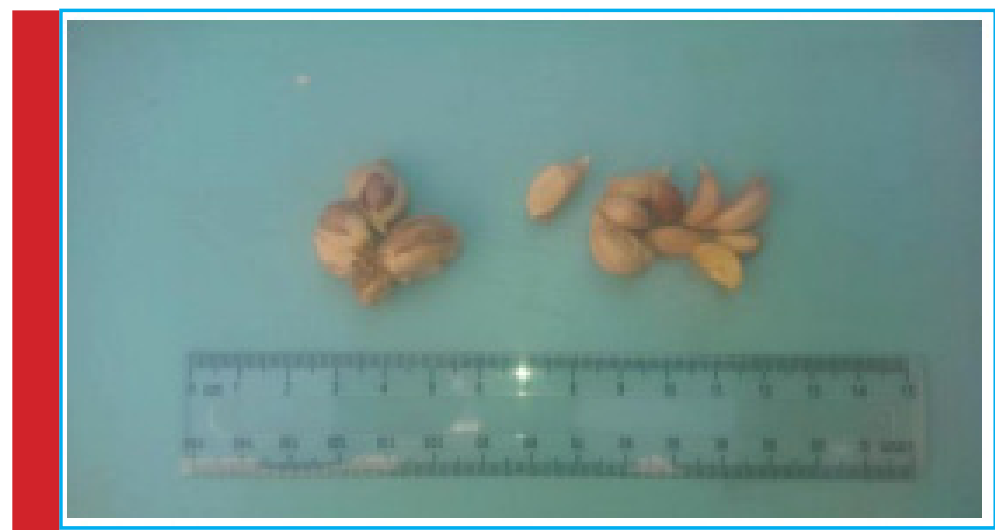

FIGURE 2. Appearance and size of the bulb (left) and cloves (right) of Zalenge garlic

\begin{tabular}{|c|c|c|c|}
\hline \multirow[t]{2}{*}{ parameter } & \multicolumn{3}{|c|}{ Results of Samples* } \\
\hline & Chinese garlic & North- Sudan garlic & Zalenge garlic \\
\hline Moisture\% & $55.57 \pm 0.21$ & $50.30 \pm 0.44$ & $40.97 \pm 0.21$ \\
\hline $\mathrm{pH}$ & $6.05 \pm 0.06$ & $5.13 \pm 0.12$ & $5.83 \pm 0.06$ \\
\hline Crude ash\% & $4.50 \pm 0.06$ & $4.53 \pm 0.3$ & $3.77 \pm 0.25$ \\
\hline Crude fibre $\mathrm{g} / 100 \mathrm{~g}$ & $2.04 \pm 0.06$ & $4.03 \pm 0.35$ & $4.03 \pm 0.45$ \\
\hline Crude protein $\mathrm{g} / 100 \mathrm{~g}$ & $5.00 \pm 0.60$ & $6.50 \pm 0.40$ & $6.73 \pm 0.50$ \\
\hline Carbohydrate $\mathrm{g} / 100 \mathrm{~g}$ & $23.97 \pm 1.06$ & $29.00 \pm 1.00$ & $38.17 \pm 1.26$ \\
\hline Fat $g / 100 \mathrm{~g}$ & $0.57 \pm 0.21$ & $1.23 \pm 0.25$ & $2.53 \pm 0.45$ \\
\hline Phosphorus mg/100g & $99.11 \pm 3.72$ & $90.22 \pm 1.66$ & $110.00 \pm 2.45$ \\
\hline Calcium mg/100g & $148.21 \pm 3.28$ & $176.60 \pm 1.20$ & $185.22 \pm 2.47$ \\
\hline
\end{tabular}

lar to, or lower than levels reported by some previous studies, Rossella et al. (2016) reported $180 \mathrm{mg} / 100 \mathrm{~g}$ of $\mathrm{Ca}$, besides other studies reported higher Ca levels. A notable variation was observed in the concentration of the mineral $\mathrm{Ca}$ between the two Sudanese samples from one hand and the Chinese garlic from the other hand. The amount of trace minerals contained in garlic is a function of their presence in the soil on which they were grown (Stephen \& John 2000).

We couldn't obtain precise and certain values of thiosulfinates in the different trials of the three garlic types. The non-precise thiosulfinates results may be due not only to the technical uncertainty of our laboratories and the unavailability of the pure standards, but may also be due to the unstable nature of the allicin compound, that (thiosulfinates) were converted giving rise to a wide variety of derived sulfur compounds (Lanzotti 2005). The allicin content of the Iranian garlic ecotypes ranged from 0.16-13.0 mg/g (Baghalian et al. 2000). Stephen \&t John (2000) reported that allicin content of Califor- nia garlic is higher than in the Chinese garlic (Alejandra 2010).

Although Eugeniusz (2007) couldn’t detect allicin or allin in powdered garlic, he found 11.12 of allin, and 4.91 of allicin in the raw garlic bulbs. In contrast, Miron (2004) found a level of $10 \mathrm{~g} / \mathrm{kg}$ alliin at most in powdered garlic. Others reported a range of $2.5-5.1 \mathrm{mg} / \mathrm{g}$ as a total allicin-yield of fresh, crushed garlic, but Miron found higher allicin levels at $37 \mathrm{mg} / \mathrm{g}$ in crushed raw garlic. Iberl (1990) stated that, upon crushing, allin quantity is about double of the allicin of the raw garlic bulb.Although our study preferred to neglect to report these uncertain results, we expect the existence of a high total allicin-yield of Zalenge garlic more than other garlic types because Zalenge garlic had higher contents of most of the natural constituents, higher density, flavor, and stronger taste.These variations were explained by the difference in the genetic variations of the garlic types, differences in the environmental conditions and soil ecology. 


\section{CONCLUSION}

Results revealed the variations on the levels of some active constituents of the three garlic tested types. Particularly, Zalenge garlic (grown in South-Western Sudan) was heavier, denser, and had more flavor than Chinese garlic which had bigger bulbs and easily peeled. Zalenge garlic contains higher levels of carbohydrate, fat, phosphorus, and calcium than the imported Chinese garlic, these higher concentrations may improve the taste and flavor of Zalenge garlic. Determination of physicochemical properties is a necessary step to identify and obtain data on the nutritional value of each garlic type. This study remains unfortunately insufficient for characterization of different African garlic types, which need to be completed by a further quantitative analysis. The chemistry behind garlic health-promoting effects was not fully understood, and the safety of allicin to treat infections in people was still unclear.

\section{ACKNOWLEDGMENT}

The authors gratefully acknowledge the approval and the support of this research study by the grant no (7463-SAR-2017-1-8-F) from the Deanship of Scientific Research at Northern Border University, Arar, K.S.A.

\section{REFERENCES}

AOAC 2008. Association of Official Agricultural Chemists. Official Methods of Analysis. Assoc. of analytical chemists. Gaithersburg. DW. Washington DC: USA. 2008.

Ahmed E A, Nouria AH, Mohammed ali GH, and Dinar HMA. (1984) Present horticultural crop production and future prospective in the Northern region. Acta Hort. 143: 59-66.

Alejandra Cardelle-Cobas, Ana Cristina Soria, Marta CorzoMartínez and Mar Villamiel. (2010) A Comprehensive survey of garlic. In: Garlic Consumption and Health .Editors: M. Pacurar, G. Krejci, pp. 1-60, 2010 Nova Science Publishers, Inc. Chapter 1. ISBN: 978-1-60741-642-5

Ashraf Y. Nasr (2014) Protective effect of aged garlic extract against the oxidative stress induced by cisplatin on blood cells parameters and hepatic antioxidant enzymes in rats. Toxicology Reports. Volume 1: Pages 682-691

Baghalian K, Ziai SA, Naghavi MR, Badi HN, and Khalighi A. (2005) Evaluation of Allicin Content and Botanical Traits on Iranian Garlic (Allium sativum L.). Ecotypes. Scientia Horticulturae, 103:155-166.

Beretz A. and Cazenave JP. (1991) Old and new natural products as the source of modern antithrombotic drugs. Planta Med. 57: S68-S72.

Block E. (2010) Garlic and Other Alliums: The Lore and the Science. Royal Society of Chemistry, Cambridge, UK: p 454.
Butt MS, Sultan MT, and Iqbal J. (2009) Garlic: nature's protection against physiological threats. Crit Rev Food Sci Nutr. 49, 6: 538-51. doi: 10.1080/10408390802145344.

Cavallito CJ, Buck JS, Suter CM. (1944) Allicin, the Antibacterial Principle of Allium sativum. II. Determination of the Chemical Structure. J. Am. Chem. Soc., 66: 1952-1954.

Cruz J.De La, and García HS. (Eds) (2007) Garlic: Post-harvest operation. Food and Agriculture Organization of the United Nations. Retrieved from: www.fao.org/fileadmin/user_upload/ inpho/docs/Post_Harvest_Compendium.

Emad Mohamed Abdallah (2017) Potential Antifungal Activity of Fresh Garlic Cloves (Allium sativum L.) from Sudan. Journal of Biotechnology Research ISSN(e): 2413-3256, ISSN(p): 24138878 Vol. 3, No. 11: pp 106-109, URL: http://arpgweb.com/?ic =journalEtjournal $=16$ tinfo $=$ aims

Eugeniusz Grela R, Renata Klebaniuk. (2007) Chemical composition of garlic preparation and its utilization in piglet diets. Institute of Animal Nutrition, Faculty of Biology and Animal Husbandry, Agricultural University, Akademicka 13, 20-934 Lublin, Poland. Article in Medycyna weterynaryjna 792 Medycyna Wet. 2007, 63 (7)

Factfish website, (2017). Sudan: Garlic, production quantity (tons). Available: http://www.factfish.com/statisticcountry/ sudan/garlic,+production+quantity

Food and Agriculture Organization of the United Nations, Statistics Division (FAOSTAT). 2017. Garlic production in 2016: Crops/World Regions/Production Quantity (from pick lists)"Retrieved 20 March 2018.

Hahn G. (1996) Garlic: the science and therapeutic application of Allium sativum $\mathrm{L}$ and related species (2nd ed.). Williams and Wilkins, Baltimore 1-24. ISBN 0-683-18147-5.

Harris JC, Cottrell SL, Plumer S, and Lloyd D. (2001) Antimicrobial properties of Allium sativum (garlic). Appl Microbiol Biotechnol, 57: 282-286.

Hassan Khalid, Wail Elsadig Abdalla, Haider Abdelgadir, Till Opatz, and Thomas Efferth (2012) Gems from traditional north-African medicine: medicinal and aromatic plants from Sudan. Review Nat. Prod. Bioprospect. 2: 92-103. DOI 10.1007/ s13659-012-0015-2

Huzaifa U, Labaran I, Bello AB and Olatunde A. (2014) Phytochemical Screening of Aqueous Extract of Garlic (Allium sativum) bulbs. Rep Opinion. 6, 8: 1-4. (ISSN: 1553-9873). http:// www.sciencepub.net/report

Iberl B, Winkler G, Muller B, and Knobloch K. (1990) Quantitative determination of allicin and alliin from garlic by HPLC. Planta Med. 56: 320-326.

Lanzotti V. (2005) The analysis of onion and garlic. J. Chromatogr. A.1112: 3-22. doi: 10.1016/j.chroma..12.016. [PubMed].

Lawson LD, Ransom DK and Hughes BG (1992) Inhibition of whole blood platelet aggregation by compounds in garlic clove extracts and commercial garlic products. Thromb. Res. 65: $141-156$.

Leyla Bayan, Peir Hossain, Koulivand and Ali Gorji1(2014) Garlic: a review of potential therapeutic effects. Avicenna J Phytomed. 4,1: 1-14. 
Libner Nonnecke Ib. (1989) Vegetable Production. Springer. pp. 312-316. ISBN 978-0-442-26721-6. Retrieved 20 June 2013.

Makoto Ichikawa, Nagatoshi Ide, Jiro Yoshida, Hiroyuki Yamaguchi, and Kazuhisa Ono. (2006). Determination of Seven Organosulfur Compounds in Garlic by High-Performance Liquid Chromatography. American Chemical Society. J. Agric. Food Chem., 54 , 5: 1535-1540.

Miron T, Bercovici T, Rabinkov A, Wilchek M, Mirelman D. (2004) [3H] Allicin: Preparation and Applications. Analytical Biochemistry. 331: 364-369.

Mohammed Ali GH and El-Sayed IA. (1999) The response of two garlic varieties (Allium satvium L.) to different planting dates in the arid tropics of Northern Sudan. Emir.J.Agric.Sci . 11: 31-40.

Mostofa ME, Choudhury MA, Hossain, et al. (2007) Antidiabetic effects of Catharanthus roseus, Azadirachta indica, Allium sativum and glimepride in experimentally diabetic induced rat. Bangladesh J Vet Med, 5, 1 and 2: 99-102.

Muhammad Ibrahim, Shafiullah, Muhammad lyas, Faraz Ali Shah, Abid Khan, Shah Rukh, and Inzimam Ul Haq. (2018) Comparison of Different Garlic (Allium sativum) Varieties for Yield and Yield Components Grown at Agriculture Research Station, Buner. Int J Environ Sci Nat Res. 13, 5. Reviewed from IJESNR.MS.ID.555873 (2018).
Nouria AH (1994) Effects of planting methods and seed rates on yield, yield components and quality of garlic (Allium satvium L.) in the Sudan. Acta Hort. 358: 359-364.

Renton A. (2013) The best garlic varieties: a guide. Food \& drink Word of Mouth blog. In : https://www.theguardian.com/lifeandstyle/wordofmouth/2013/0ct/08/bestgarlic-

Rossella Vadalà, Antonio F. Mottese, Giuseppe D. Bua, Andrea S. (2016) Statistical Analysis of Mineral Concentration for the Geographic Identification of Garlic Samples from Sicily (Italy), Tunisia and Spain. Foods. 5, 1: 20.

Saha M and Bandyopadhyay P K. (2017) Phytochemical screening for identification of bioactive compound and antiprotozoan activity of fresh garlic bulb over trichodinid ciliates affecting ornamental goldfish'. Aquaculture. 473: 181-190.

Sha Li, Hor-Yue Tan, Ning Wang, Zhang-Jin Zhang, Lixing Lao, Chi-Woon Wong, and Yibin Feng (2015) The Role of Oxidative Stress and Antioxidants in Liver Diseases. Int J Mol Sci. 16, 11: 26087-26124.

Shah CS, Qudry JS. (1996) A Text Book of Pharmacognosy. 15th ed. B.S. Shah Prakashan, Ahmedabad p. 119.

Stephen F. \& John B. (2000) Garlic: Nature's Original Remedy. Healing Arts Press : Rochester. 